Ks. Michał CHŁOPOWIEC ${ }^{*}$

\title{
POKUTNA PEREGRINATIO WE WCZESNYM ŚREDNIOWIECZU
}

Idea pielgrzymowania w sensie aktu religijnego stanowi rodzaj wirtualnej kontynuacji wydarzeń biblijnych o przypisywanej im wartości symbolicznej, niekoniecznie interpretowanych w taki sam sposób u ich genezy. Najstarszym bodaj motywem inspirującym tego typu zachowania było polecenie Jahwe dane Abrahamowi: „Wyjdź z twej ziemi rodzinnej i z domu twego ojca i idź do ziemi, którą ci wskażę" (Rdz 12, 1). Interpretację teologiczną owemu wydarzeniu nadał List do Hebrajczyków $(11,8-10)$ w stwierdzeniu, że ,przywędrował on do Ziemi Obiecanej jako ziemi obcej [...] oczekując miasta zbudowanego na silnych fundamentach, którego architektem i budowniczym jest sam Bóg”. Dla chrześcijan treść tego polecenia odzwierciedla wyrażony nakaz nieprzywiązywania się do spraw doczesnych, lecz zdążania ku niebieskiemu Jeruzalem. Gdziekolwiek więc by się oni mieli znajdywać i w jakimkolwiek stanie żyć, są nieustannie uczestnikami pielgrzymki do ostatecznej ojczyzny Bożej obietnicy (por. 2Kor 5, 6).

Nie wydaje się jednak, by wymienione teksty biblijne, przy całym przypisywanym im interpretacyjnym wkładzie, odegrały znaczącą rolę w intensyfikacji praktyki pielgrzymowania, niemniej uzupełnione wyrażonym w różnych formach stwierdzeniem Chrystusa, że Syn Człowieczy nie ma gdzie głowy skłonić, dostarczały kierunkowych przesłanek dla określenia postaw ascetycznych, jako sposobu oczyszczania zmysłów i przebóstwiania przez podejmujących owe dzieło własnego człowieczeństwa.

\section{Teologiczne motywy peregrinatio $\mathrm{i}$ ich realizacja na syro-egipskim} wschodzie. Pielgrzymowanie w krąg swoich zainteresowań włączyli na sposób pionierski ludzie poszukujący dróg religijnej doskonałości, głównie ci wybierający życie wsparte świadectwem nadzwyczajnych poświęceń należnych tylko Bogu, co zresztą stanie się z czasem impulsem dla postępującego ilościowo powstawania wspólnot monastycznych.

\footnotetext{
${ }^{*}$ Ks. dr hab. Michał Chłopowiec - emerytowany profesor Papieskiego Wydziału Teologicznego we Wrocławiu; były kierownik Katedry Teologii Moralnej Szczegółowej; e-mail: ks.M.Chlopowiec@archidiecezja.wroc.pl.
} 
Temu stawiającemu radykalne wymogi nowemu zjawisku daje początek wybór pustyni jako uprzywilejowanego miejsca ascezy dokonany przez św. Antoniego Pustelnika (ok. 250-356), którego od podejmujących podobne działania poprzedników różniło radykalne zerwanie ze światem. Można przypuszczać, że wybór dokonywał się nie bez udziału bodźców poza religijnych, spośród których najbardziej rzucały się w oczy, właśnie w Egipcie, relacje społeczne obciążone permanentnie uciążliwym przeludnieniem wynikającym z dysproporcji pomiędzy niewielką powierzchnią ziem uprawnych i liczbą mieszkańców. Sąsiedztwo zamieszkiwanych osad z pustynią stanowiło w istniejącej sytuacji rodzaj propozycji schronienia się przed zgiełkiem zatroskanego o byt, bądź nie rzadko szukającego igrzysk tłumu. Na pustynię ponadto jako miejsce swoistego azylu przed wrogim światem wskazywali, ze względów wcale nie idealistycznych, skłóceni najczęściej z prawem uciekinierzy, np. chłopi pozostawiający pola $\mathrm{z}$ intencją wymuszenia na właścicielach lepszych warunków pracy, czy szukający sposobów uniknięcia wykonania wyroku różnego typu przestępcy. Przebywali oni tam wprawdzie okresowo, ale pośrednio pokazywali, że minimum warunków egzystencji pustynia oferuje.

$\mathrm{W}$ ten zobrazowany wyżej kontekst wpisuje się również pustynia jako miejsce doświadczeń mistycznych, przedstawiając propozycję dla szukających w atmosferze przez nią stwarzanej uprzywilejowanej drogi do własnego duchowego wnętrza, mającym na względzie pogłębienie kontaktu z Bogiem. Permanentny brak wody, której trudne pozyskanie zajmowało co najmniej dwa dni drogi, nie zachęcał oczywiście ascetów do osiedlania się tam na stałe i w tym właśnie kontekście decyzja Antoniego ma znaczenie przełomowe. Ów z przyczyn ascetycznych dokonywany wybór określano mianem anachoretyzmu oznaczającego opuszczenie dotychczasowego miejsca przebywania z zamiarem układania sobie życia na pustyni ${ }^{1}$.

Ruch anachoryczny został zapoczątkowany na przestrzeni III w. w Egipcie na gruncie korzystnej sytuacji mocnego i już dobrze ugruntowanego, charakteryzującego się wysokim stopniem neofickiej gorliwości chrześcijaństwa. Wiara w tych okolicznościach dynamizowała stawiane przez Ewangelię wymogi etyczne, nadając im w konkretnych odniesieniach rangę wyższej konieczności. Jeżeli więc zamieszkiwanie na pustyni zyskało wartość porównywalnego z męczeństwem świadectwa powierzenia się Bogu do końca, to podjęcie takiego zadania posiadało dla wielu rangę osiagnnięcia życiowego, naśladującego pójście na krzyż z miłości.

W naśladowaniu św. Antoniego ów rozwijający się ruch nabierał dynamiki w oparciu o panującą żywiołowość i spontaniczność, obywając się z powodzeniem bez jakichkolwiek formalnych regulacji. Te zastępował panujący entuzjazm i usprawiedliwiał fakt, że zręby organizacyjne wymagają odpowiedniego czasu na dojrzewanie. Stanowi rzeczy sprzyjała także okoliczność właściwej

${ }^{1}$ Por. E. Wipszycka, Egipt - ojczyzna mnichów, w: Apoftegmaty Ojców Pustyni, t. 1: Gerontikon. Księga Starców, red. M. Starowieyski, ŹM 4, Kraków - Tyniec 2004², 18. 
dla ludzi Wschodu niechęci do przyporządkowywania życia zbyt sztywnym i rygorystycznym regułom. Najstarsze w konsekwencji eremickie zgromadzenia, choćby o sławie Pispiru, Nitrii czy Sketis (z założycielami kolejno Antonim, Ammunem i Makarym Egipskim) były w swojej organizacyjnej formie dalekie od klasztorów, posiadając raczej charakter ośrodków eremickich.

Centra owe wytyczały początkowe ścieżki mniszej duchowości, zasługując ze względu na ich pionierską działalność na najwyższe uznanie, co nie zmienia faktu, że brak uregulowań dyscyplinujących stwarzał warunki dla rozwoju tendencji negatywnych, nieregularności i trendów degeneratywnych. Dotyczyło to mniej samej treści, bardziej natomiast wyciaganych wniosków. Następstwem były powstające hybrydy, niezamierzone wprawdzie, lecz odpowiadające logice przyjętych założeń.

Wyróżnia się w tym względzie napiętnowany przez Rzym, znany z rygorystycznych żądań ruch kontestacyjny donatystów. Bez wchodzenia w szczegóły stawianych przez jego zwolenników tez, zwraca uwagę równoległa lub identyczna radykalizacja $\mathrm{w}$ wyżej wymienionych kwestiach, naśladująca czyny pustelników, choć w odmiennych zupełnie sektorach. Cele do osiaggnięcia tam stawiane (zbyt z pewnością idealistyczne na owe czasy, znajdujące dla powyższych racji oddźwięk przede wszystkim wśród warstw najmniej uprzywilejowanych) były w dużej mierze słuszne, wszakże wątpliwości budziły daleko idące, kuriozalne niejednokrotnie sposoby ich realizacji, nawet przy założeniu działań motywowanych religijnie. Twarz tego ruchu stanowili aktywiści pogardliwie zwani circumcelliones, rekrutujący się na ogół z niewolników, kolonów i drobnych właścicieli. Bez posiadania własnego miejsca zamieszkania, krążyli oni wokół chat chłopskich, prowokując przyjętym stylem bycia lekceważące ich traktowanie, wyrażone w określeniu właśnie circum cellas vagabantur $^{2}$, z jakich to słów utworzono ich skrótowe, pogardliwe w rzeczy samej nazwanie ${ }^{3}$.

${ }^{2}$ Ich postulaty poprawienia doli warstw najuboższych były niewątpliwie ewangeliczne, lecz moralnie nie do zaakceptowania okazały się stosowane przez nich metody, z których najbardziej radykalne to dokonywanie rabunków czy wymuszanie siłą likwidacji zapisów dłużniczych. Bardziej skrajnym ich odgałęzieniem, zwłaszcza w Syrii, byli nazywani wędrującymi mnichami asceci, o kuriozalnych, wręcz czasem niebezpiecznych praktykach, jak żywienie się trawą (ßoбкoí), poszukiwanie zimą schronienia bez najprostszych zabezpieczeń, zamieszkiwanie latem miejsc pod gołym niebem, uznawanie za chwalebne traktowanie siebie w imię wypróbowania pokory za mało rozgarniętych umysłowo, chodzenie nago jako symbolu podobieństwa $\mathrm{z}$ anielską duchową istotą niewrażliwą na zróżnicowania płciowe i wrodzone człowiekowi poczucie wstydu. Por. F. Drączkowski, Donatyzm, EK IV 112; H. von Campenhausen, Die asketische Heimatlosigkeit im altkirchlichen und frühmittelalterlichen Mönchtum, Tübingen 1930, 4-5. Myśli w tym ostatnim opracowaniu zawarte będą niejednokrotnie przewijać się w prezentowanym niniejszym omówieniu.

${ }^{3}$ Również w Kościele Zachodnim we wczesnym średniowieczu dochodzi do podobnych zniekształceń powodowanych przez monachi girovagi bądź circuite. Z circumcelliones łączą ich jednak bardziej zewnętrzne niż światopoglądowe podobieństwa, ponieważ ostatni z nich inspirowani byli określoną ideologią, nawet jeżeli błędną, to jednak ideologią. Kieruje więc nimi jakiś określony cel do osiągnięcia, czego nie da się powiedzieć o girovagi, których jako nieformalną grupę jedynie wy- 
Wracając jednak do dzieła św. Antoniego powiedzieć trzeba, że jako propozycja ascetyczna o wyjątkowym wymiarze, miało ono charakter przekonywującego wzorca, szybko znajdującego rzesze naśladowców. Objawiało się to w powstawaniu licznych skupisk anachoreckich, zakładanych z zasady przez wybijające się, gromadzące wokół siebie zwolenników jednostki. Nie stawiano tam żadnych wymogów regulaminowych po prostu dlatego, że ich nie było. Projekt duchowy i jego realizacja wchodziły w takim znaczeniu w zakres osobistych decyzji kandydatów. W powstałym więc kontekście, organizacyjne wymogi nie odgrywały żadnej w zasadzie roli, ustępując miejsca zamiarowi ascetycznemu.

Wybór środków prowadzących do zbawienia musiał w konsekwencji skutkować niczym nieograniczonym indywidualizmem, prowadzącym nie rzadko do niekontrolowanych działań przybierających w konkretnych przypadkach cechy groteskowości. Objawiły się one np. w stosowanych, niekoniecznie zresztą dla wszystkich miejsc reprezentatywnych praktykach, gdzie z jednej strony budzi podziw surowość obieranych ćwiczeń ascetycznych, z drugiej wszakże rodzi pytania sensowność ich podejmowania. Wśród nich bywają czynności w dużej mierze szokujące, a przynajmniej mocno dyskusyjne. $\mathrm{Na}$ wymienienie zasługują choćby takie, jak spożywanie przez 5-7 dni ograniczonej do minimum ilości chleba; jedzenie go w formie nadpsutej lub ekstremalnie wysuszonej; konsumowanie surowych warzyw, żywienie się trawą również na sposób bydlęcy i pozostawanie w trwającym nieraz lata wystawionym na piekące słońce obmurowanym jedynie ścianami pomieszczeniu. Do ascetycznych umartwień należał także spoczynek nocny w obieranej celowo niewygodnej pozycji lub na siedząco, czy też niekorzystanie całymi nocami ze stojącego obok łóźka. Te spośród wielu innych wybrane przykłady charakterystyczne dla istniejących tendencji uprawdopodobniają przekonanie, że zakres praktykowanych wówczas ascetycznych ćwiczeń nie wykraczał zbytnio poza gamę umartwień, jakich w omawianej kwestii może dostarczyć wyobraźnia $^{4}$. Ale niezależnie od oceny podejmowanych wtedy pokutnych czynów, nie ulega wątpliwości, że przenikał je duch składanej Bogu ofiary, niezwykłej, bo nierzadko wymagającej krańcowo wielkich wyrzeczeń.

Wielkości poświęceń niekoniecznie odzwierciedlają osiagnnięte rezultaty, a czasami wręcz pojawiają się odczuwalne za ich pośrednictwem (o genezie religijnej) przeciążenia, skutkujące odradzającymi się zniechęceniami. Następstwem są kryzysy, które niezażegnane przeradzają się w przeciwieństwo założonego do osiagnięcia celu. Ratunkiem w warunkach pustyni stają się

różniają łączące ich luźno wspólne interesy. Odpowiadają więc oni raczej profilowi pasożytniczej o właściwościach toksycznych narośli, bez jakiejkolwiek struktury organizacyjnej. Nie realizują wręcz z założenia dążeń wspólnotowych, natomiast przyporządkowują wspólnoty własnym osiaganym na manipulacyjny sposób, skrajnie egoistycznym celom. Ich ocena przez ówczesne kościelne autorytety jest jednoznacznie negatywna. Do finalnego rozpadu tej grupy przyczyni się najradykalniej potępiająca mnisze włóczęgostwo reguła św. Benedykta.

${ }^{4}$ Por. J. Wagemann, Entwicklugsstufen des ältesten Mönchtums, Tübingen 1929, 9. 
wówczas napomnienia mistrzów, niekoniecznie założycieli eremickich ośrodków, lecz niejednokrotnie w prowadzonych dialogach uznanych autorytetów posługujących innym mądrością ubogaconą przemyśleniami i w warunkach pustynnej ascezy dojrzewającą radą.

Wiele $\mathrm{z}$ owych konwersacji dotarło do nas w formie spisanych apoftegmatów. Należą do nich np. ideały do zrealizowania przedstawione w opowiadaniu Makarego Egipskiego uczestnikom mszy ojca Pambo ${ }^{5}$. Pomimo uznanej przez innych jego pozycji wielkiego duchowego mistrza oraz założyciela mniszej wspólnoty, stwierdza on w sposób dla słuchaczy raczej niespodziewany, że nie jest jeszcze mnichem, lecz mnichów widział po wyjściu z celi w Sketis, przemierzając drogę $\mathrm{w}$ głąb pustyni. Na wysepce, w środku znajdującego się tam jeziorka służącego za wodopój dla dzikich zwierząt, zobaczył dwóch nagich ludzi. Na pytanie skąd są, usłyszał odpowiedź, że z pewnego klasztoru, a na pustyni przebywająjuż czterdzieści lat, nie wiedząc nawet, co się dzieje w świecie. Gdy Makary zagadnął, czy on sam mógłby zostać mnichem, usłyszał: mnichem nie może stać się ktoś, kto nie wyrzeknie się wszystkiego, co jest na świecie. Skonfrontowany z taką konstatacją Makary oświadczył wtedy: wobec tego ja jestem zbyt słaby, aby spełnić warunki stawiane mnichowi. Usłyszał wówczas w odpowiedzi: tedy siedź w celi i opłakuj swoje grzechy.

Jak z samej nazwy wynika, mnisi wędrowni nie stanowili grup zorganizowanych, co nie znaczy, że ich luźna struktura nie podlegała procesom ewolucyjnym powodowanym bądź siłą pojawiających się od wewnątrz idei, bądź też wnoszonych przez wielkich mistrzów korekt z zewnątrz, przenikających do wspólnot $\mathrm{w}$ postaci nowych spojrzeń i interpretacji.

Jednym z elementów ukierunkowujących mniszą praktykę, wcześniej wprawdzie obecnych, lecz stabilizujących bardziej niż kreatywnych, było pojęcie obcości, $\xi \varepsilon v \imath \tau \varepsilon i ́ \alpha$, słowa o treści wieloaspektowej, wyznaczającego rozumiane szeroko kryteria odnoszące się zarówno do sposobu bycia mnichów wędrownych, jak i tych, którzy preferowali zamknięcie się we własnej celi, dotyczące wyznaczających na miejsce pobytu inne kraje oraz przebywających już na obczyźnie jako nikomu nieznani przybysze. Do kwestii tej nawiązuje w prowadzonej rozmowie, ubocznie w rzeczy samej, bez wszakże przypisywania zalecanym praktykom rangi środków gwarantujących zbawienie, opowiadanie abby Ammonasa ${ }^{6}$. Treść jego pouczeń ujmuje na sposób wielce skondensowany, w formie komentarza wzmianka abby Andrzeja stwierdzającego, że „trzy rzeczy przystoją mnichowi: przebywanie na obczyźnie ( $\xi \varepsilon v \imath \tau \varepsilon i ́ \alpha)$, nędza i milczenie z cierpliwością"?.

Naznaczone obcością w realizowanym przez niego dziele odchodzenia od świata życie mnicha, przyjmuje stopniowo wyraźnie zróżnicowane formy.

${ }^{5}$ Por. Apophtegmata Patrum 455, thum. M. Borkowska, w: Apoftegmaty Ojców Pustyni, PG 35, 260-261, ŹM 4, s. 328.

${ }^{6}$ Por. tamże 116, PG 65, 120, ŹM 4, 174.

${ }^{7}$ Tamże 152, PG 65, 136, ŹM 4, 192. 
Najpierw (niekoniecznie w porządku chronologicznym) jawi się wewnątrz grup eremickich potrzeba wyzbywania się wzajemnych zależności bądź powiązań pomiędzy braćmi w przypadku, gdy posiadają one negatywny wpływ na zachowanie autonomii w urzeczywistnianiu stawianych duchowych celów ${ }^{8}$. Innym aspektem jest uzyskanie w miejscu przebywania zdolności wyrzeczenia się wszystkiego, rzeczy i działań tak, jakby się przebywało na obczyźnie9. Jednak pobyt na obczyźnie niekoniecznie ogranicza się do pozostawienia jedynie rodzinnych stron, lecz $\mathrm{w}$ języku ascezy posiada również zasięg niekonwencjonalny, taki np. jak, „panowania człowieka nad swoim językiem”10 według określenia abby Tithoesa.

Wbrew prostym regułom semantycznym ,bycie obcym” nie przybierało więc koniecznie kierunku na zewnątrz, rodzaju nastawienia misyjnego, lecz także pielgrzymowania do własnego wnętrza z równoczesnym na sposób radykalnego oddalania się od „świata”, co anonsuje postulat zamknięcia całej życiowej przestrzeni do własnej celi. Nie jest z pewnością łatwo znaleźć w wypowiedzi któregoś z Ojców Pustyni sformułowanego motywu tak wyrażonego dezyderatu, ale w formie życzeniowej odkryć go można w cytowanej wyżej wypowiedzi abby Ammonasa ${ }^{11}$ postulującego, aby unikać spotkań z innymi. Ów dezyderat potwierdza również własnym zachowaniem abba Paweł Wielki ${ }^{12}$, czy abba Serapion doprowadzający do nawrócenia jawnogrzesznicę, która pokutując za grzechy, podjęła ostry post, zamykając się na stałe we własnej celi ${ }^{13}$.

Jakkolwiek zamieszkiwanie na pustyni oraz opuszczenie własnej ojczyzny z intencją udania się do obcego kraju, czy wreszcie zamknięcie się we własnej celi, musiały budzić respekt i stanowić uznany wyraz niezwykłego oddania się Bogu, to decyzje takie nie wszędzie przyjmowane były z entuzjazmem. Z wypowiedzi np. abby Matoesa ${ }^{14}$ wynika, że od podobnych typów ascezy przynajmniej się dystansował ośrodek w Sketis, gdzie z kolei zwracano uwagę na realne skutki ujemne podniesionej do rangi obowiązującej reguły izolacji. Przy określonych splotach okoliczności bowiem, jak dowodzono, przyjąć może ona kształt bardziej ucieczki niż cnoty, co się z dużą wyrazistością ujawnia $\mathrm{w}$ przypadkach wspólnego zamieszkiwania z niełatwym do zaakceptowania bratem, z którym się dzieli jedno pomieszczenie. W takich okolicznościach trzeba również z nim okazać solidarność nie tylko biernie, ale przy oznakach miłości czynnej, dając w ten sposób wiarygodne świadectwo prawdziwego ducha złożonej Bogu ofiary. Zacieśniając ponadto samotność do niej samej, według opinii reprezentowanej przez ośrodek w Sketis, pomija się fakt, że

\footnotetext{
${ }^{8}$ Por. tamże 88, PG 65, 112, ŹM 4, 166.

${ }^{9}$ Por. tamże 779, PG 65, 373-376, ŹM 4, 434.

${ }^{10}$ Tamże 911, PG 65, 427, ŹM 4, 492.

${ }^{11}$ Por. tamże 116, PG 65, 120, ŹM 4, 174.

${ }^{12}$ Por. tamże 796, PG 65, 381, ŹM 4, 445.

${ }^{13}$ Por. tamże 875, PG 65, 413-416, ŹM 4, 476.

${ }^{14}$ Por. tamże 516-519, 522, 525, ŹM 4, 355n.
} 
przebywający w jednej celi współbracia stanowią dla siebie przecież wsparcie, nie tylko w przypadku pokusy wyjścia poza granice wierności Bogu ${ }^{15}$.

Do kanonu cnót w sensie miary mniszej doskonałości wprowadzają progresywnie Ojcowie Pustyni również posłuszeństwo. Świadectwo temu daje abba Rufus wynosząc wręcz ową cnotę ponad wszelkie inne akty ascetyczne, przytaczając na poparcie przyjętego stanowiska wizję mającą miejsce we śnie jednego z Ojców, który relacjonując jej treść opowiadał o czterech hufcach w niebie, gdzie w prezentowanej przez nich gradacji najwyższe miejsce zajmował hufiec posłusznych, noszący na znak wyróżniającej go rangi złote naszyjniki i tarcze ${ }^{16}$.

Ewoluujące w stronę zorganizowanej struktury, przy uwzględnieniu aspektu hierarchicznego ośrodki mnisze, znajdują odzwierciedlenie przyjętego kierunku w pierwszej bodaj zakonnej na Wschodzie regule zredagowanej przez św. Bazylego Wielkiego (329-379), dla którego z kolei podstawowy warunek postępu duchowego upatrywany był w stabilitas loci rozumianym nie w sensie bezwarunkowego zamknięcia się przed „światem”, lecz pogłębiania braterstwa pomiędzy mnichami, środowiska więc tworzącego uprzywilejowany kontekst dla czynnej miłości bliźniego ${ }^{17}$.

Uhierarchizowanie życia mnichów musiało skutkować wymogami zarówno posłuszeństwa, jak i zaakceptowaniem stabilitas loci jako miejsca przywracania równowagi duchowej po jej utracie w wyniku ludzkich słabości. Przypisywaną mu wagę ilustruje wydarzenie w Sketis, gdzie niewymieniony z imienia brat skarży się abbie Arseniuszowi na dręczące go myśli, powodujące stan niezdolności ani do postu, ani do pracy, dlatego jak mówi, poszedł opiekować się chorymi, gdyż „to także jest miłość”. W udzielonej odpowiedzi abba Arseniusz dał mu następujące pouczenie: „Wracaj i jedz, pij, śpij, żadnej pracy nie wykonuj - tylko się z celi nie oddalaj”, gdyż jak twierdzi, właśnie wytrwanie w celi doprowadza mnicha do doskonałości ${ }^{18}$. Sytuacja paralelna ma miejsce w przypadku brata proszącego o radę abbę Mojżesza, którego odpowiedź na zadane pytanie ma brzmienie analogiczne: „Idź, usiądź w swojej celi, a cela cię wszystkiego nauczy"19. O powszechności tak wyrażonego przekonania świadczy wreszcie reakcja abby Arseniusza, który rozmawiając z pewnym bratem o podobnych wątpliwościach, już wcześniej zaciagającego rady u abby Pafnucego i Jana ${ }^{20}$ stawia żądanie o treści niemal identycznej.

Zalecenie powracania przy różnego rodzaju życiowych okolicznościach do celi identyfikowane było niekoniecznie z zakazem zakonnej migracji, a nawet

${ }^{15}$ Por. tamże 725, PG 65, 360, ŹM 4, 419.

${ }^{16}$ Por. tamże 802, PG 65, 389-392, ŹM 4, 453.

${ }^{17}$ Por. K. Holl, Enthusiasmus und Bussgewalt beim griechischen Mönchtum, Hildesheim 1969, 160n.

${ }^{18}$ Apophtegmata Patrum 49, PG 65, 89, ŹM 4, 150.

${ }^{19}$ Tamże 500, PG 65, 284, ŹM 4, 349.

${ }^{20}$ Por. tamże 790, PG 65, 380, ŹM 4, 442. 
z czasem wręcz przyjęło charakter niepisanej reguły wyrażonej w nieprzywiązywaniu się do miejsc przebywania, ponieważ - jak takie żądanie motywowano - przeciwieństwo może stanowić potencjalne zagrożenie wskazujące bardziej na szukanie wygody, niż na oddanie się ascezie. Jeżeli bowiem mieszkasz tam, gdzie wzbudzasz u ludzi zazdrość, twierdził abba Pojmen, wiedz, że nie postąpisz w życiu duchowym ${ }^{21}$. Oddany w pełni Bogu mnich bowiem nie przywiązuje się do niczego, gdy zaś sytuacja staje się groźna dla jego życia duchowego, musi mieć odwagę zrezygnowania bez żalu z rzeczy nawet najpotrzebniejszych. Przykładem jest abba Ammoem, który po rozłożeniu do wyschnięcia na słońcu należących do niego pięćdziesięciu miar pszenicy (ok. 37 litrów), gdy spostrzegł, że coś może w miejscu obecnego przebywania zaszkodzić jego duszy, zabrał uczniów i odszedł z tamtej okolicy. Na pytanie, dlaczego tak przydatne rzeczy pozostawia i odchodzi, odpowiedział przykładem wiernych, pozostawiających w imię obrony swoich przekonań nie tylko chleb, lecz także wielkie, symbolizowane $\mathrm{w}$ tym przypadku pomalowanymi drzwiami bogactwa ${ }^{22}$.

Po raz kolejny nie oznacza to, że miejsce przebywania należy opuszczać $\mathrm{z}$ błahych powodów, bo łatwe nieodchodzenie $\mathrm{z}$ raz zamieszkałego miejsca należy według abby Antoniego do trzech ważnych postanowień, takich jak nieustanna świadomość obecności Boga i odniesienie do Pisma Świętego, od czego w rzeczy samej zależy zbawienie ${ }^{23}$. Anachoreta bowiem musi pamiętać, że wybiera pustynię na miejsce dochodzenia do doskonałości nie po to, by prowadzić jakiegokolwiek rodzaju życie towarzyskie, lecz z wyznaczonym celem intensyfikacji kontaktu z Bogiem, dlatego każda wizyta z zewnątrz nie pozostaje bez powodowania szkody, stanowiąc wręcz coś więcej niż tylko wyraz ludzkiej słabości ${ }^{24}$.

Zasięg więc pojęcia $\xi \varepsilon v \imath \tau \varepsilon i ́ \alpha$ jest w regułach mniszych nie zawsze jednoznaczny, czerpiąc swoją treść z niejednokrotnie mu towarzyszącego kontekstu, raz z akcentem postawionym na uchodźctwie bądź pielgrzymowaniu w znaczeniu fizycznego przemieszczania się, innym razem na bezdomności w sensie duchowym, jako metodzie osiagania podwyższonego stopnia pokory, doskonałego ubóstwa i obwarowanego milczeniem pokoju. Zaznaczyć ponadto warto, że idea bezdomności jako czyn ascetyczny nie niesie sensu w sobie, lecz nabiera go zasługując na miano ofiary w służbie troski o duszę i stanowi wyraz szeroko pojętego wkładu edukacyjnego.

\section{Wzorzec ascezy wschodniej w spotkaniu $z$ duchowością Kościo-} la zachodniego. Kościół zachodni dla racji oczywistych nie mógł pozostać

${ }^{21}$ Por. tamże 592, PG 65, 325, ŹM 4, 392.

${ }^{22}$ Por. tamże 134, 128, ŹM 4, 181.

${ }^{23}$ Por. tamże 3, PG 65, 76, ŹM 4, 137.

${ }^{24}$ Por. tamże 45, PG 65, 89, ŹM 4, 150; 75, PG 65, 104, ŹM 4, 160. Zob. ponadto w kwestii Ojców Pustyni analizę Karla Heussi (Der Ursprung des Mönchtums, Tübingen 1936, 206n), którego szereg myśli zostało wykorzystanych również w omawianym tutaj temacie. 
obojętny na wzorce duchowości wypracowane na Wschodzie (syryjskim bądź egipskim), głównie ze względu na propozycję dotychczas nie praktykowaną, radykalnego (łącznie z posuniętą do ekstremu ofiarą samotności) oddania siebie na służbę Bogu, ale również z racji wzajemnego przenikania się obu przecież bliskich sobie duchowości.

Bliskość jednak nie oznacza identyczności, zwłaszcza że Zachód i Wschód dzieliło szereg rozbieżności, choćby takich, jak różnice mentalnościowe, wrażliwość religijna, odrębne tradycje czy nawet subtelności w szeregowaniu kryteriów moralnych. Wymienić w tym kontekście również trzeba odczucia związane z pustynią, na egipsko-syryjskim Wschodzie doświadczaną jako spalona słońcem ziemia, na Zachodzie zaś w sensie mniej lub bardziej niedostępnego, znaczącego ascezę odmiennym sposobem bycia pustkowia. $\mathrm{Na}$ Wchodzie ponadto priorytety wyznaczał zawsze kierunek na uduchowienie, na Zachodzie w podtekście tkwi zaś wyczuwalna nieustannie zasada praktyczności, wskazująca na preferencje dla wartości służebnych. Za ilustrację tych tendencji uznać można wyrażone w liście św. Ambrożego do biskupa Euzebiusza z Vercelli dążenie do powiązania duchowości mniszej z ośrodkami miejskimi. Wyrażone tam zostało mianowicie uznanie, że inaczej niż Eliasz, Elizeusz czy Jan, właśnie Euzebiusz jako „mnich” pozostał wierny zadaniom posługi pasterskiej ${ }^{25}$ i pasterskiej misji.

Nawiązując do negatywnie ocenianych doświadczeń charakterystycznych dla początków tworzącej się mniszej duchowości powiedzieć trzeba, że na Zachodzie kwestia wędrujących mnichów (w znaczeniu monachi girovagi) odgrywała (być może także pod wpływem pejoratywnych sygnałów przychodzących ze Wschodu) rolę raczej marginesową. Mnichów tego rodzaju postrzega się tu głownie jako ludzi nieprzewidywalnych, traktując ich w kategoriach istniejących w Kościele problemów do rozwiązania. Stanowią więc oni przede wszystkim przedmiot surowej krytyki i nie rzadko przepełnionych sarkazmem recenzji, co łatwo dostrzec w opiniach reprezentatywnych autorytetów tamtego czasu. Przykładowo św. Augustyn charakteryzuje owych wędrowców w słowach: „nusquam missos, nusquam fixos, nusquam stantes, nusquam sedentes"26 i dodaje, że przemieszczając się z miejsca na miejsce trudnią się oni niewybrednie bardziej handlem niż duchowością. Ostrych słów nie szczędzi im również Benedykt z Nursji w zredagowanej przez siebie Regule, gdzie we wstępnym już rozdziale dokonując swoistej oceny i gradacji zakonników, umieszcza włóczących się mnichów w ostatniej, najmniej chlubnej grupie, wyrażając o nich opinię niedwuznacznie niepochlebną takimi słowami:

„Czwarty rodzaj mnichów to ci, których nazywają mnichami wędrującymi.

Przez całe życie szwendają się oni po różnych okolicach, goszcząc po trzy lub

${ }^{25}$ Por. Ambrosius Mediolanensis, Epistula 63, PL 16, 1187; 66, PL 16, 1224-1227; 67, PL 16, 1227-1231.

${ }^{26}$ Por. Augustinus Hipponensis, De opere monachorum 28, PL 40, 575. 
cztery dni w rozmaitych klasztorach. Zawsze się włóczą, pozbawieni wszelkiej stałości, służąc tylko własnym zachciankom i rozkoszom podniebienia"27.

Nie deformacje rzecz jasna leżały na pierwszym miejscu w centrum zainteresowania mistrzów duchowości na Zachodzie, lecz wytyczane przez ascetów Wschodu drogi do doskonałości, z charakterystyczną dla nich cechą nadawaną greckim pojęciem $\xi \varepsilon v ı \tau \varepsilon i ́ \alpha$. Wzorce stamtąd czerpie wielu ascetów, najczęściej anonimowych, ale również takich $\mathrm{z}$ imionami wpisanymi w historię chrześcijańskiej doskonałości. Na wymienienie w tym kontekście zasługują choćby postaci o wielkości Rufina z Akwilei (ok. 345-411), Melanii Starszej (ok. 342-410), Hieronima ${ }^{28}$ (345 lub 347-419 lub 420), Kasjana (360-435) czy kilka dziesięcioleci później Germana z Paryża (ok. 496-576). Przedsiębrali oni podróże na Wschód w celach głównie studyjnych z intencją przeniesienia proponowanych wzorców duchowości ze Wschodu na Zachód, uznając za drugorzędne uzasadnienia teoretyczne (których zresztą poza Kasjanem i kwestiach przedstawianych w kazaniach i listach Hieronima szukać można było głównie w apoftegmatach), z pierwszeństwem nadawanym sposobom uprawiania ascezy. Jako rodzaj streszczenia tych intencji potraktować można wypowiedź wyrosłego na doświadczeniach europejskich, współczesnego Ambrożemu i Augustynowi, Paulina z Noli (354-431), który to dla motywów głównie religijnych opuściwszy własną ojczyznę (Hiszpanię) i spędziwszy wiele lat w założonej przez siebie mniszej wspólnocie, zachęca swego przyjaciela do zrobienia podobnego kroku z takim oto uzasadnieniem:

${ }^{27}$ Benedictus, Regula 1, PL 66, 246: „Quartum voro genus, est monachorum quo nominatur gyrovagum, qui tota vita sua per diversas provintias ternis aut quaternis diebus per diversorum cellas hospitantur, semper vagi, et nunquam stabiles, et propriis voluptatibus et gulae illecebris servientes", thum. zbiorowe, w: Starożytne reguly zakonne, PSP 26, Warszawa 1980, 191.

${ }^{28}$ Jego refleksje dotyczące omawianego tematu są o tyle mało interesujące, że akcent przenosi on z peregrinatio a patria na peregrinationes ad loca santa, wskazując na Palestynę jako na cel pielgrzymowania. Nadaje przy tym słowu pereginatio odcień odmienny od greckiego $\xi \varepsilon v \imath \tau \varepsilon i ́ \alpha$, przypisując wartość zasługi głównie włożonemu trudowi dotarcia do miejsc świętych. Stwierdzenia te wszakże nie mają jak się wydaje, znaczenia zawężającego, wykluczającego rozumienie wschodnie, lecz sens zaanonsowanego, dodatkowego jej wariantu. Wniosek taki narzuca się w zestawieniu z polemicznym przeciwstawieniem owej propozycji Klaudiusza Mamerta, ustosunkowującego się krytycznie do sposobu pielgrzymowania nazywanego „lokalnym”, żądającego niejako korekty metody w dążeniu do osiagnnięcia celu oraz określenia samego celu, jakim z założenia jest opanowanie pożądliwości ciała. Konieczne więc jest tu z natury rzeczy dokonanie nawiązania do wartości o zabarwieniu ascetycznym. Ten aspekt został podkreślony w następującej jego wypowiedzi Klaudiana Mamerta: „Nie chcemy dłużej zatrzymywać się jako pielgrzymi w Aleksandrii, ale raczej powracać z Egiptu do ojczyzny prawdy, przepłynąć morze błędów i przejść przez pustynię ignorancji (non diutius ad Alexandriam peregrinemur, sed ab Aegypto redeuntes transmisso errorum mari et emensa ignorantiae eremo, veritatis patriam atque uti terram repromissionis intremus" (tenże, De statu animae 9, 3, PL $53,771)$. Ideał obcości w takim kontekście przypisany zostaje życiu chrześcijańskiemu rozumianemu jako wędrówka duchowa przebiegająca w poczuciu swoistego rodzaju alienacji wobec całego świata. 
„W imię pomnożenia twojego stanu łaski i miłości (Boga), opuść twoją ojczyznę, ponieważ będąc jeszcze w ciele błąkasz się daleko od Chrystusa"'29.

Podobny również kierunek obiera urodzony w prowincji Panonia (teren prawdopodobnie dzisiejszych zachodnich Węgier) Marcin z Tours (316/317-397), przed wyborem na biskupa żyjący jako mnich w założonej przez siebie pustelni w Ligugé ${ }^{30}$.

3. Irlandzko-brytyjskie akcenty w rozumieniu peregrinatio. Rolę pośrednicząca w przekazie egipsko-syryjskich idei anachoreckich i eremickich odegrała głównie Europa południowa, a przede wszystkim jej prowincje łacińskie i Galia. Tam zdobyte doświadczenia dojrzewały, ale formę oryginalną przyjęły na wyspach brytyjskich, za sprawą pochodzących z południa i w tamtym regionie powstałych lub tam tłumaczonych literackich źródeł: Vita Martini Sulpicjusza Sewera, Vita Antonii Anastazego w przekładzie Evagriusza z Antiochii, Apophtegmata Patrum oraz innych z greckiego na łacinę przełożonych pism Ojców Pustyni lub ich dotyczących, zwłaszcza Jana Kasjana, znawcy i popularyzatora monastycyzmu i ascetyzmu wschodniego, nie bez racji zaliczanego do Ojców Pustyni. Właśnie jego De Coenobiorum Institutis i Collationes stanęly u podstaw oryginalnej ascezy celtyckiej.

Spotkanie monastyczno-ascetycznych praktyk Wschodu z rodzimymi tendencjami nie mogło na odległych od tamtych miejsc wyspach brytyjskich obejść się bez dokonywanych korekt wymuszanych znacznymi, choćby już wyżej wspomnianymi różnicami. Dlatego nie tyle miał tu miejsce proces kopiowania, ile raczej asymilacji, czy wręcz dokonującej się pomiędzy wartościami syntezy. Stało się bowiem oczywiste, że przy fizycznej nieobecności pustyni, warunkowana przez nią samotność przyjmowała inną formę niż ta o podobnej treści, lecz realizowana w warunkach zupełnie odmiennych. Dlatego chęć poświęcenia się Bogu w izolacji od świata przybiera w nowej sytuacji inny wyraz ${ }^{31}$.

U Celtów, ale i ogólnie w krajach brytyjskich, właściwości pustyni są zamiennie przypisywane morzu i w jego właśnie otoczeniu asceci będą na Wyspach $^{32}$ szukać miejsc realizacji, pokrewnych Ojcom Pustyni, wymogów

${ }^{29}$ Paulinus Nolanus, Epistula 5, 24, PL 61, 174: „Pro gratiae vel caritatis augmento peregrinaris a patria, dum adhuc hospes corporis peregrinaris a Christo", thum. własne.

${ }^{30}$ Towarzyszyło temu oczywiście wiele innych wydarzeń i okoliczności. Opisuje je współczesny św. Marcinowi w poświęconym mu życiorysie Sulpicjusz Sewer (Vita sancti Martini, ed. J. Fontaine, SCh 133, Paris 1967).

${ }^{31}$ Por. A. Angenendt, Monachi peregrini, München 1972, 159.

${ }^{32} \mathrm{~W}$ tym kontekście nie bez znaczenia również jest zakorzeniony w tradycji irlandzkiej fakt przypisywania wyspom charakteru świętości, dlatego były one przedmiotem czci w sobie. Z tego też względu także zaświaty przedstawiano w formie wyspy; por. F. Le Roux - C.J. Guyonvarc'h, Keltische Religion, w: Handbuch der Religionsgeschichte, cz. 1, hrsg. J.P. Assmusen, Göttingen 1971; A. Angenendt, Die irische Peregrinatio und ihre Auswirkungen auf dem Kontinent vor dem Jahre 800, w: Die Iren und Europa im früheren Mittelalter, hrsg. H. Löwe, cz. 1, Stuttgart 1982, 57. 
samotności. Bez zastrzeżeń zaakceptowane zostają wskazania Kasjana, dla którego życie mnisze ma prowadzić do naznaczonego samotnością życia kontemplacyjnego. Dochodzi więc do wprowadzania w praktykę, szczególnie od końca VI w., anachoretyzmu wręcz czasowego, charakteryzującego się przebywaniem długimi okresami na odległych miejscach w atmosferze podyktowanej ascezą samotności. Później jednak progresywnie się ustala, przybierający nawet charakter instytucjonalny, anachoretyzm sezonowy o szczególnego rodzaju rytmie, bo regulowanym porami roku. Praktyka ta charakteryzowała się tym, że na początku lata mnich zwany „doskonałym” udawał się na wybrzeże, gdzie się osiedlał na skale oddalonej z reguły od terenów zamieszkiwanych. Ze względu na warunki klimatyczne nie mógł tam przebywać w zimie, dlatego każdy sezon ascetycznej kontemplacji był cyklicznie przerywany i według zamiarów powtarzany. W tym przypadku także, jak w starożytności, ideałem było pozostawanie ,żołnierzem Chrystusa”, o wierności naznaczonej nawet męczeńskim oddaniem życia ${ }^{33}$.

Mnisi irlandzcy przystępują do takiej praktyki inspirowani hasłem peregrinatio pro amore Dei, a więc opuszczenia własnej ojczyzny z zamiarem udania się do obcego kraju ze względu na okazywaną Bogu miłość. W tych kategoriach należy także rozumieć praktykę udawania się gromadnie na określony czas, duchownych i świeckich, do zakładanych przez św. Kolumbana klasztorów z zamiarem odpokutowania swoich win, której to praktyki ślady znajdujemy w znanych nam dzisiaj, pochodzących z tamtego czasu, klasztornych regułach ${ }^{34}$.

Wydaje się więc, że nazwę peregrinus przypisywano głównie ludziom decydującym się na opuszczenie własnego kraju (Irlandię/Anglię) ${ }^{35}$, z intencją dobrowolnego udania się na obczyznę, co dobitnie potwierdza fakt, że wielkość dokonanego w tej materii dzieła oceniano według kryteriów pokonanego dystansu pomiędzy krajem opuszczanym i docelowym, realizując w ten sposób uchodźctwo w pełnym tego słowa znaczeniu. Peregrinatio ponadto interpretowano w Irlandii jako „służbę Bogu w pokucie"36. Stąd nieustanna dominacja właśnie takiego rodzaju motywacji w życiu świętych irlandzkich i stosowanie formuł ,pielgrzymowanie dla imienia Pana”, ,dla miłości Chrystusa”, „dla zdrowia duszy”, czy „w celu zdobycia niebieskiej ojczyzny”37. Określone w ten sposób wymogi pozostają zresztą w wyraźnym odniesieniu

\footnotetext{
${ }^{33}$ Por. J. Leclercq, De Saint Gregoire à saint Bernard du VI au XII siècles, w: La spiritualité du Moyen Âge, éd. J. Leclercq - F. Vandenbroucke - L. Bouyer, Paris 1961, 30n.

${ }^{34}$ Por. Jonas Bobiensis, Vita Columbani I 3, ed. B. Krusch, MGH Scriptores Rerum Germanicarum XXXVII, Hannoverae - Lipsiae 1905, 157: „Relicto ergo natali solo”, thum. E. Zakrzewska-Gębka, w: Św. Kolumban, Pisma, Jonasz z Bobbio, Żywot Kolumbana, PSP 60, Warszawa 1995, 197: „Opuścił ziemię rodzinną”.

${ }^{35}$ Por. Angenendt, Monachi peregrini, s. 151-152.

${ }^{36}$ Ten rodzaj zrównania w wartości potwierdzony jest w tekście wydrukowanym w The Ancient Laws of Ireland (Rolls Series), III, Dublin - London 1873, 3, cyt. za Leclercq, De Saint Gregoire, s. 59.

${ }^{37}$ Tamże.
} 
do charakteru narodowego Irlandczyków, łączących kontemplację z ponawianym ciągle wysiłkiem pozyskiwania leżącej gdzieś w tajemniczej oddali mitycznej ojczyzny.

W powyższym również obramowaniu dopatrzeć się można organizacyjnego tła tworzonych przez wielkiego ich rodaka, Kolumbana, ośrodków zakonnych z formacją o ewidentnie dwukierunkowym wymiarze: tendencjach kontemplacyjnych z jednej i nachylenia misyjnego z drugiej strony. Pierwszą z nich, na sposób w dużej mierze symboliczny, obrazuje obranie już u progu jego mniszej działalności za punkt codziennego przebywania niewielkiej, wówczas z pewnością niezamieszkanej, usytuowanej u południowych wybrzeży Szkocji wyspy Iona, drugą zaś, intensyfikacja działań ewangelizacyjnych na kontynencie, o przewodniej idei uwidocznionej ponad dwa wieki później w wezwaniu następcy Kolumbana, Smaragda z Mihiel, nawiązującego do sztandarowego dla Ojców Pustyni polecenia danego Abrahamowi, udania się do innego kraju. Dostrzec tu także można okrężny jakby powrót do stosowanej u Ojców Pustyni interpretacji peregrinatio wybrzmiałej w stwierdzeniu, że kraju wskazanego przez Boga nie powinien mnich szukać poza sobą, lecz w sobie, bo miejscem docelowym każdego podejmowanego religijnego pielgrzymowania jest kraina cnoty ${ }^{38}$.

Nie ulega więc wątpliwości, że oba rozumienia peragrinatio wyprowadzone są z tego samego źródła, choć sposób dochodzenia do celu jest odmienny. Różnica tkwi w przesunięciu akcentów, o efekcie końcowym odgraniczenia obu sposobów spojrzenia.

Istniejące subtelności ilustruje potraktowanie jako reprezentatywnego dla każdej ze stron ewangelicznego wezwania do doskonałości o treści wprawdzie paralelnej, lecz innym wyrazie. Jeżeli mianowicie w działaniach św. Antoniego oraz naśladujących go ascetów hasłem sztandarowym było wezwanie: „Jeżeli chcesz być doskonałym, idź sprzedaj to, co posiadasz i rozdaj ubogim, a będziesz miał skarb w niebie. Potem przyjdź i chodź za mną" (Mt 19,21), to mnichom irlandzkim ze względu na splot istniejących tam okoliczności i uwarunkowań bliższy był odpowiednik o nieco innym odcieniu: „Kto dla mego imienia opuści braci lub siostry, ojca lub matkę, dzieci lub pole, stokroć więcej otrzyma i życie wieczne odziedziczy" (Mt 19, 29). Na Wschodzie bowiem preferencje ogołoceniu dawała w sposób naturalny bliskość pustyni, w Irlandii natomiast sugestia taka mogła mieć charakter jedynie teoretyczny, ponieważ determinowana ubogimi ziemiami permanentna bieda ludności propozycję wyzbywania się posiadanych dóbr czyniła bezprzedmiotową.

W Irlandii ponadto opuszczeniu kraju w imię wierności Mistrzowi towarzyszyła warunkowana miejscowymi tradycjami i obciążająca negatywnie taki czyn szczególnego rodzaju, wzmacniająca surowość pokutną okoliczność. Peregrinatio mianowicie jako dobrowolne opuszczenie rodu i własnej ojczyzny odnoszone było do tła tworzonego z udziałem panującego w tamtym

\footnotetext{
${ }^{38}$ Por. Smaragus Abbas, Diadema monachorum 85, PL 102, 678.
} 
czasie porządku prawnego, nadającego ubocznie takiemu czynowi jakość dużego samo-upokorzenia wynikającego z faktu piętnowanego karą wygnania najgroźniejszych przestępców. Była to kara ustopniowana w takim sensie, że zaciagnięcie poważnej (nie o najwyższej wszakże randze) winy, pociagało za sobą przymusowe wydalenie z plemienia, przestępstwa zaś kryminalne o wysokiej szkodliwości karane były banicją w najszerszym tego słowa znaczeniu. Ówczesny potencjał komunikacyjny nie otwierał zbyt wielu możliwości korekty obecnego w przestrzeni publicznej fałszywego przekonania krzywdzącego ludzi opuszczających ojczyznę z własnego wyboru. Do objawów łatwo więc dorobić było przyczynę, a do przyczyny skutek, obciążając konkretne podmioty oskarżeniami bez przedstawienia sprawdzonych argumentów. Ich ofiarami bywali więc także opuszczający swój kraj mnisi.

Przekonania owe wzmacniała stosowana dyscyplina kościelna ze słusznym skądinąd uzasadnieniem, że jednostka naruszając na poziomie poważnego skandalu standardy etyczne, staje się zagrożeniem dla porządku społecznego, powodując niegodnymi zachowaniami moralną infekcję środowiska. Wyeliminowanie takiej osoby jest więc w sensie gestu obronnego obowiązkiem władzy. Uzasadniona argumentacją moralną czy teologiczną w takim znaczeniu banicja, przyjmuje jakość oczywistości nie tylko w obszarze lokalnym, lecz również jako standard europejski, z przypisana jej podwójną rolą: penitencjarną na terenie świeckim, pokutną w obszarze kościelnym ${ }^{39}$.

Popełnionym o wysokim stopniu ciężkości winom nadawano rozumienie ekspansywne, to znaczy, że na wyjątkową karę zasługiwały nie tylko przestępstwa o randze zabójstwa, lecz również czyny oceniane w społecznym odbiorze jako zbliżone do zbrodniczych. Ich wagę powiększały np. obciążające okoliczności czy podnoszące stopień drastyczności skutki, czego przekładem mogą być cudzołóstwa o gorszących reperkusjach bądź kradzieże powiązane ze świętokradztwem. Jak wynika z zapisów pokut taryfowych odbywanych w ramach peregrinatio, adresatami tych sankcji byli nie ludzie świeccy, lecz w pierwszym rzędzie duchowni i zakonnice ${ }^{40}$. Część owych win wiązanych z wyrokiem opuszczenia ojczyzny posiadał więc podtekst dyfamacyjny ${ }^{41}$, co wielcy asceci traktowali jako sposób czynienia pokuty (wyrazistym przykładem w materii jest Kolumban Starszy) ${ }^{42}$, ale również stanowiły one swoistego rodzaju signum destinctivum ascezy mniszej. Wartości zasługującej tego rodzaju czynu nadawała - rzecz jasna - dobrowolność, bo tylko wolna decyzja

${ }^{39}$ Por. E.L. Grasmück, Exilium. Untersuchungen zur Verbannung in der Antike, Paderborn 1978.

${ }^{40}$ Opisuje je szeroko i dość szczegółowo C. Vogel (Le pèlerinage pénitentiel, RevSR 38:1964, 123-129) ze wskazaniem na penitencjały, z jakich pochodzą.

${ }^{41}$ Por. M.J. Walh, Keltische und irische Askese, TRE IV 227.

${ }^{42}$ Por. L. Bieler, Irland. Wegbereiter des Mittelalters, Olten - Lausanne - Freiburg im Breisgau $1961,74$. 
poddania się woli Bożej podnosi poczynione kroki do rangi naśladowania Chrystusa i świadczy o gotowości pójścia za Nim także na krzyż ${ }^{43}$.

Obligatoryjny postulat niesienia krzyża (por. Ef 4,4$)^{44}$ zawarty w dezyderacie: „Jeśli kto chce pójść za Mna, niech się zaprze samego siebie, niech weźmie krzyż swój i niech Mnie naśladuje" (Mt 16, 24), realizuje się w sposób najdoskonalszy w martyrium, a więc w wierności w najprostszym przekładzie okupionej śmiercią. Irlandia jednak i tutaj wniosła własne rozróżnienia, na co niewatpliwy wpływ miały dwa przynajmniej uwarunkowania. Jednym z nich było wyspiarskie jej usytuowanie, z natury rzeczy sprzyjające izolacjonistycznym czy nawet endemicznym tradycjom lokalnym, drugim zaś podłoże historyczne.

W aspekcie geograficznym usytuowanie Irlandii poza granicami Cesarstwa zabezpieczało chrześcijan przed dokonywanymi, bardzo czasem krwawymi prześladowaniami. Kościół więc irlandzki nie miał żadnego w tej kwestii doświadczenia, co sprawiało, że zabarwienia idei męczeństwa nie przydawała społeczna autopsja, lecz tylko podtekst hipotetyczny, odzwierciedlający bardziej założenia teoretyczne niż stan faktyczny. Stąd pojęcie martyrium było w Irlandii bliższe ideałowi niż gotowości do naśladowania rodzimych herosów okupujących wierność Mistrzowi oddaniem życia. Pojedyncze wprawdzie przypadki męczeńskich śmierci Irlandczyków zdarzały się, lecz tylko wówczas, gdy ktoś jako świadek wiary wiedziony imperatywem misyjnym posiewu słowa Bożego czy charakterystycznym celtyckiemu temperamentowi ${ }^{45}$ consuetudo peregrinandi, skazany był na śmierć $\mathrm{w}$ innym kraju, co wszakże nie osiagało poziomu doświadczenia narodowego.

Brak rodzimych wzorców nie musiał oczywiście sam z siebie osłabiać żywotności idei męczeństwa, a czasem wręcz u najbardziej religijnie zaangażowanych grup mógł ją wzmacniać na zasadzie idealizacji, bo przecież naśladowanie Chrystusa w Jego drodze na krzyż stanowi niezmiennie wyznacznik autentyzmu wiary. Czym innym jednak jest wzorzec, a czym innym doświadczenie. W każdym razie martyrium w randze najwyższej ofiary nie mogło pozostawać na marginesie zainteresowań uprawianej ascezy, lecz musiało się pojawić jako rzeczywistość wieloaspektowa.

Termin więc martyrium w imię wierności Bogu niekoniecznie łączono z finalnym skutkiem utraty życia, chyba że pojęcie to formalizowano i uniezależniano od nadanej mu tym sposobem treści. Wątpliwość we wspomnianym przypadku budzi bowiem fakt rozbieżności dotyczącej samego pojęcia męczeństwa w związku z narzucającym się wtedy pytaniem, czy bardziej na nazwę męczennika zasługuje człowiek torturowany, dzięki jedynie

${ }^{43}$ Por. Columbanus, Epistula 4, 6, ed. Societas Aperiendis Fontibus Rerum Germanicarum Medii Aevi, MGH Epistulae III, Berolini 1892, 167-168, tłum. E. Zakrzewska-Gębka, PSP 60, 92-93.

${ }^{44}$ Por. tamże.

${ }^{45}$ Walafridus Strabo tak formułuje ową właściwość: „Nuper quoque de natione Scotorum, quibus consuetudo peregrinandi jam pene in naturam conserva est, quidam advenientes" (Vita Sancti Galii II 47, PL 114, 1029C). 
szczęśliwemu zbiegowi okoliczności nie tracący jednak życia, czy też ten, kto utracił życie jednym uderzeniem miecza. Pochodzące z pierwszych wieków chrześcijaństwa świadectwa dowodza, że w powyższej kwestii nie było to tylko pytanie teoretyczne, lecz godność męczennika przyznawano bohaterom ekstremalnie cierpiącym za wierność Chrystusowi w jednym i drugim przypadku. Taki tok postępowania w sposób szczególnie dobitny widoczny jest u św. Cypriana w jego wyjaśnieniach dotyczących problematyki tak zwanych „listów pokoju”46.

Wieloaspektowość spojrzenia na męczeństwo, choć przy motywacji niekoniecznie identycznej, widać również w Kościele irlandzkim, uwzględniającym zróżnicowane podejście do czynienia pokuty, nadającym wcześniej uogólniającemu pojęciu nowe treści, przy rozróżnieniu jakby wielowarstwowości funkcji cierpienia znoszonego w imię wierności religijnym ideałom. W sytuacjach bowiem, gdy ból ascezy porównywalny jest $\mathrm{z}$ bólem umierania, zmieniają się kryteria męczeństwa, gdyż widziane od strony (zwłaszcza) subiektywnej przesłanki tam stosowane, tracą na jednoznaczności. W takim przypadku funkcji integracyjnej dokonuje właściwa dla ówczesnej teologii (irlandzkiej) terminologia, wyróżniająca nie jedno, lecz trzy rodzaje martyrium o nazwach symbolicznie powiązanych z nadawanymi im treściami, mianowicie męczeństwo czerwone, białe i zielone. Nazwy te odpowiadają konkretnym uwarunkowaniom, o odcieniach wszakże niekoniecznie treściowo identycznych z ich odpowiednikami na lądzie.

Męczeństwo czerwone (dergmartra) stanowi, jak łatwo się domyśleć, korelat świadectwa wiary przepłaconego życiem, z implikacją oczywiście prześladowań religijnych.

Osiagane ekstremalną ascezą w permanentnej walce ze sobą samym, mało spektakularne, naznaczone wszakże ogromnym trudem i w tym sensie bardziej na dłuższy dystans wymagające, rozłożone na całe życie, imitujące działanie autentyczne, jest męczeństwo białe (bánmartra). Jego wzorzec przedstawia opis męki Oengusa ${ }^{47}$ odnoszącego ostatecznie zwycięstwo porównywalne ze zwycięstwem nad cierpieniem Hioba.

Nie należy go wszakże rozumieć jako przeciwieństwo męczeństwa czerwonego w znaczeniu swoistej konkurencji, lecz w sensie wyrażenia innego sposobu wierności Chrystusowi w warunkach niejednokrotnie subiektywnie o wiele trudniejszych. Jakkolwiek przypisuje się mu wartość o niższej randze zasług, to stanowi ono obraz wysiłku porównywalnego z czerwonym męczeństwem. Posiada więc bardziej charakter środka niż celu, w porównaniu zaś z męczeństwem wyrażonym w utracie życia, pełni wobec niego rolę służebną. Realizacja ideału męczeństwa białego może się w takim sensie dokonać tylko

\footnotetext{
${ }^{46}$ Por. M. Chłopowiec, Pokuta w Kościele pierwszych wieków, Wrocław 2015, 90.

${ }^{47}$ Por. The Martyrology of Oengus the Culdee, Dublin 1984, 139.
} 
drogą całkowitego ofiarowania siebie Bogu, czego wyrazem są podejmowane na sposób permanentny surowe umartwienia ${ }^{48}$.

Sama koncepcja i kształt męczeństwa białego, odpowiada w dużej mierze, miejscowym tradycjom oraz charakterowi narodowemu Irlandczyków, odznaczających się skłonnościami do gwałtowności i charakterem przechodzącym łatwo w skrajności, co znajduje - siłą rzeczy - odzwierciedlenie także w życiu religijnym. Kontekst ów warunkował również niezwykłą żarliwość pokutną dostrzegalną $\mathrm{w}$ ekstremalnie nieraz ostrej ascezie realizowanej w wyjątkowo wymagających umartwieniach, podobnej w zakresie niezwykłej surowości, przynajmniej w praktyce, do monastycyzmu wschodniego, wyrażonego w bezgranicznym ubóstwie, ograniczaniu do całkowitego minimum snu i posiłków oraz stosowanie postów niemal absolutnych. Niektóre z owych praktyk oceniane $\mathrm{z}$ dzisiejszego punktu widzenia byłyby mało lub całkowicie nieakceptowalne, choćby te w rodzaju (ważnej przecież dla racji higienicznych) rezygnacji z kąpieli, stania w lodowatej wodzie, całkowitej rezygnacji z życia towarzyskiego uskutecznianej podczas długich okresów milczenia, przebywania w przedłużającej się samotności czy posuniętego do ekstremu posłuszeństwa ${ }^{49}$.

Najmniej bodaj precyzyjna jest treść męczeństwa zielonego, najpierw ze względu na niedookreśloność użytego przymiotnika, gdyż irlandzkie słowo glas niekoniecznie musi się odnosić do koloru zielonego (jak trawa), lecz oznaczać także barwę szarą (jak popiół), bladość (człowieka zmarłego), a także barwę niebieską. Trudności w jego określeniu sprawia ponadto płynność granicy pomiędzy męczeństwem białym i zielonym. Mimo wszystko jednak ślady odnośnego nazwania można napotkać we wczesnym średniowieczu. Najbardziej chyba wyczerpująco wyjaśnia je jeden z ówczesnych kaznodziejów w takim mniej więcej określeniu: ten uczestniczy w męczeństwie zielonym, kto przez wyrzeczenia i trudy dla osiagnięcia skruchy i czynienia pokuty narzuca granice własnym pragnieniom ${ }^{50}$. Sformułowanie to wskazuje, że przez męczeństwo zielone rozumie się w pierwszym rzędzie pełną skruchy, po wyznaniu zaciągniętej winy, gotowość do wynagrodzenia wyrządzonych szkód. Znaczenie takie odzwierciedlają także sformułowane przez Kościół celtycki reguły zawarte w pochodzących z tamtego okresu penitencjałach, gdzie wielkość pokut zadawanych za poszczególne grzechy określano drobiazgowo

\footnotetext{
${ }^{48}$ Męczeństwo białe wydaje się odpowiadać kryteriom mortificatio, którego interpretacje mogą być różne. Przykładowo, autor życiorysu Kolumbana sprowadza je do trzech głównych postaw: nienoszenia w sercu zadry, zachowania dyskrecji oraz zdyscyplinowania wyrażonego $\mathrm{w}$ nieoddalaniu się według własnych upodobań od miejsca stałego pobytu. Ten ostatni postulat w przypadku mnicha dotyczy głównie posłuszeństwa przełożonemu w sensie przedłużenia posłannictwa Zbawiciela zstępującego z nieba nie po to, aby pełnić swoją wolę, lecz wolę Ojca (por. J 6, 38).

${ }^{49}$ Por. H.I. Marrou, Od prześladowań Dioklecjana do śmierci Grzegorza Wielkiego (303-604), w: J. Danielou - H.I. Marrou, Historia Kościoła, t. 1: Od poczatków do roku 600, tłum. M. Tarnowska, Warszawa 1986, 337.

${ }^{50}$ Por. Irische Kanonensamlung, hrsg. F.W.A.H. Wasserschleben, Giesen 1874, 70-71.
} 
jako przewlekłe posty, powtarzane uklęknięcia, leżenie krzyżem, zamknięcie w klasztorze, a także długie pielgrzymki, łącznie z podróżami zamorskimi ${ }^{51}$.

Uwagę zwraca również okoliczność, że pojęciu peregrinatio w Kościele pierwotnym nie przypisywano nigdy charakteru pokutnego w sensie zadośćuczynienia wymaganego za popełniony grzech. Taki sens nadają mu dopiero na przełomie VI i VII w. księgi pokutne (penitencjały) najpierw z terenu brytyjskiego (głównie irlandzkiego), gdzie jest wymieniany obok innych aktów zadośćuczynnych takich np. jak post czy przypisane modlitwy, a także pokutne zadania wspomagające opanowanie ciała i wzmocnienia ducha.

Warto $\mathrm{w}$ aspekcie toczących się zmian nadmienić również, że w XIII w. peregrinatio posiada już zasięg powszechny i wymieniane jest wśród pokut najcięższych. Jako takie nakładane zostaje na grzeszników obarczonych czynami skandalizującymi, bulwersującymi społeczność. Ów sposób działania odnosi się oczywiście do każdego z winnych, lecz w pierwszym rzędzie kary tego typu mają chronić powagę duszpasterską kleru, przestrzegając metodą mocnych skarceń przed podobnego rodzaju czynami.

Praktyka peregrinatio jako pokutnego czynu wymagającego poświęceń utrzymuje się przez kilka wieków, aż do pojawienia się zagrażających jej celowi tendencji degeneratywnych. Stają się one w XIII w. na tyle powszechne, że sensowność pokutnego pielgrzymowania podważają wielkie teologiczne

${ }^{51}$ Por. L. Gougaud, Les conception du martyre chez les Irlandais, RBen 24 (1907) 369-370. Autor ów wyjaśnia również połączenia pomiędzy kolorem zielonym a pokutą z miejscowymi tradycjami liturgicznymi Irlandii. Otóż u genezy tego leży najpierw system zwany Arreae, znany nam ze zredagowanego ok. VIII w. po łacinie penitencjału, skąd się dowiadujemy o redukcjach ekstremalnie trudnych do wykonania pokut, do krótszych, lecz o bardziej intensywnym charakterze. Dla uniknięcia paszczy piekła, jak mówiono, zanurzali się bohaterowie męczeństwa zielonego w nocne czuwania w modlitwie, leżąc krzyżem (crosfigell), śpiąc na łóżku pokrytym łupinami z orzechów, a nawet spoczywając w trumnie ze znajdującymi się tam zwłokami; lub też praktykując czarne posty polegające na niespożywaniu niczego o kolorze białym, mleka, sera czy jaj, bez ujmowania czegokolwiek normalnym postom nakazanym. Zauważyć należy, że pokucie zawsze towarzyszyła atmosfera w ścisłym znaczeniu smutku oraz kolory ciemne wyrażające żałobę, połączenie zaś koloru zielonego z męczeństwem miało powody inne, bardziej określone, których wyodrębnienie zakłada dokonanie bardziej precyzyjnych rozróżnień. W starożytności chrześcijańskiej mianowicie nakładano szatę pokutną nakłaniając do wylewania łez i skruchy. Fragment tekstu wyjętego z uchwał drugiego synodu św. Patryka donosi: „De poenitentia post ruinas. Statuitur ut abbas videat cui attribuetur potestas alligandi et solvendi; sed aptior est, juxta Scripturae exempla, veniam. Si vero cum fletu et lamentatione et lugubri cum veste, sub custodia poenitentia brevis, quam longa et remissa cum temperamentis" (Synodus Sancti Patrici 3, PL 53, 819). Konfrontując dane z Labar Breec w kwestii symboliki ośmiu kolorów, dowiedzieć się można, że barwa zielona jest kolorem żałoby. Czytamy tam mianowicie, że „kto przybiera się w kolor zielony, powinien mieć odczucie przepełnionego serca i ducha wielkim przygnębieniem i skrajnym bólem; ponieważ kolor ten ma przypominać o ukrytym pod wzgórkiem ziemi u końca życia grób: zieloną jest bowiem u swych początków cała ziemia" (cyt za: Gougaud, Les conception du martyre chez les Irlandais, s. 370-371). Jakkolwiek takie wyjaśnienie połączenia koloru zielonego z męczeństwem mogło by wydawać się na pierwszy rzut oka dziwne, to jednak pochodzące $\mathrm{z}$ tamtego czasu teksty potwierdzają taką interpretację (tamże). 
autorytety czasu, takie jak Tomasz z Akwinu czy Durand z Saint-Pourçain († 1334 lub 1332) stwierdzający, że praktyki podobnego rodzaju są bardziej przyczyną pojawiających się skandali niż środkiem uświęcenia. Idea jednak pokutnego pielgrzymowania choć nieco przyciemniona przetrwała jeszcze długo, do tego stopnia, że w XVIII w. podpisany na synodzie rzymskim (1725) przez Benedykta XIII dokument potwierdza wcześniej posiadaną rangę pokutną czynów przyporządkowanych właśnie pojęciu peregrinatio ${ }^{52}$.

Zaznaczyć niniejszym również warto, że równolegle odżywa inna zrodzona na bazie pokutnego pielgrzymowania praktyka - biczowanie, wchodząca w użycie jako dzieło pokutne w XIII w., ale rzeczywiste jej odrodzenie dokonało się w wieku XVII, głównie za przyczyną Jana Gretser'a, uzasadniającego teologicznie ważną rolę pokuty dla życia duchowego metodą biczowania w traktacie De disciplinis, co przy wsparciu zachęt czynionych przez spowiedników sprawiło, że praktyka ta u najgorliwszych chrześcijan przetrwała dłużej niż same podejmowane w celach pokutnych pielgrzymki ${ }^{53}$.

Przedstawione aspekty pielgrzymowania są z założenia fragmentaryczne, bowiem zakres omawianej $\mathrm{w}$ tym aspekcie tematyki jest na tyle szeroki, że każda z poruszonych kwestii otwiera nowe wątki z właściwymi sobie pytaniami. Przykładem moga być choćby teologiczne i pastoralne uzasadnienia peregritatio w pielgrzymkach regionalnych czy miejscowych, w późniejszym zaś czasie pokutne implikacje nawiedzania miejsc świętych (Rzymu, Jerozolimy, Compostelli, sanktuariów lokalnych), oceny równoległych z pozytywnym rozwojem formuł degeneratywnych $\mathrm{w}$ wariancie niejednokrotnie tylko koncepcyjnym, choć nie rzadko również stosowanych w praktyce.

Podsumowując więc zaprezentowane wyżej refleksje w zakresie pokutnego pielgrzymowania, żywe zwłaszcza we wczesnym średniowieczu, trzeba powiedzieć, że posiadające z założenia charakter pokutny peregrinatio nie jest dziełem o wartości jednowymiarowej, lecz - zależnie od przypisywanej jej funkcji - przechodzi w odcienie wręcz kontrastowo różne, od ascezy o inspiracjach indywidualistycznych, sprowadzonych do osobistej walki z utrapieniami pustyni, poprzez rezygnację (w przypadku mnichów) z powiązań rodzinnych, realizację celów misyjnych, do sposobu bycia wyrażonego $\mathrm{w}$ formule stabilitas in peregrinatione. Jak więc z powyższego wynika, nie przemieszczanie się stanowi rozpoznawczą cechę pielgrzymowania, lecz rozumiana $\mathrm{w}$ sensie $\xi \varepsilon v \imath \tau \varepsilon i ́ \alpha$ bezdomność przyporządkowująca życie człowieka woli Boga, aż do granicy całkowitego wyrzeczenia się siebie.

\footnotetext{
${ }^{52}$ Por. Concilium Romanum (1725), Indictio, Mansi XXXIV 1849-1850.

${ }^{53}$ Por. Vogel, Le pèlerinage pénitentiel, s. 114-115.
} 
PENITENTIAL PEREGRINATIO IN THE EARLY MIDDLE AGES

\section{(Summary)}

Pilgriming is generally understood as a kind of motivational, religious mowing to "saint places" revived by the atonement intention (to rarely thankful) for God given goodness, which is subjectively believed to be meaningful. In thereby interpretation, only visible aspect comes to the foreground, without getting into its theological proof.

In hereby elaboration, however, the topic of theological issue is touched upon, not in a sense of a detailed meaning of the notion, but by showing the historical determinations conditioning the way of understanding the notion.

In Christian bastion of the discussed phenomenon is the Middle East, from where the solutions have been transferred to the West, in somewhat different categories. The transfer, both in theory and in practice, could be possible only due to people's engagement, who were fascinated with the eastern spirituality. Some of the famous names, who could be distinguished are Jerome, John Cassian or Melania the Elder, the most active figures.

The idea of pilgrimage transferred to the west, hasn't been, clearly, intact in its form, but exposed to, based on different local accents, evolutionary changes. It is shown in interpretation changes applied, in reference to the notion of peregrinatio, inland and in the British Isles.

Key words: the Early Middle Ages, Spirituality, Anachoritism, Atonement.

Slowa kluczowe: wczesne średniowiecze, duchowość, anachoretyzm, pokuta.

\section{BIBLIOGRAFIA}

\section{Źródła}

Ambrosius Mediolanensis, Epistulae, PL 16, 876-1286.

Apophtegmata Patrum, PG 65, 71-440, thum. M. Borkowska: Apoftegmaty Ojców pustyni, t. 1: Gerentikon. Księga Starców, red. M. Starowieyski, ŹM 4, Kraków - Tyniec $2004^{2}$.

Augustinus Hipponensis, De opere monachorum, PL 40, 547-582.

Benedictus, Regula (cum commentariis), PL 66, 215-912, thum. zbiorowe, w: Starożytne reguty zakonne, PSP 26, Warszawa 1980, 188-233.

Columbanus, Epistulae, ed. Societas Aperiendis Fontibus Rerum Germanicarum Medii Aevi, MGH Epistulae III, Berolini 1892, 156-190, tłum. E. Zakrzewska-Gębka, w: Św. Kolumban, Pisma, Jonasz z Bobbio, Żywot Kolumbana, PSP 60, Warszawa 1995, 79-106.

Concilium Romanum (1725), Indictio, Mansi XXXIV 1849-1850.

Irische Kanonensamlung, hrsg. F.W.A.H. Wasserschleben, Giesen 1874.

Jonas Bobiensis, Vita Columbani, ed. B. Krusch, MGH Scriptores Rerum Germanicarum XXXVII, Hannoverae - Lipsiae 1905, 148-228, thum.E. Zakrzewska-Gębka, w: Św. Kolumban, Pisma, Jonasz z Bobbio, Żywot Kolumbana, PSP 60, Warszawa 1995, 185-220. 
Mamertus Claudianus, De statu animae, PL 53, 697-780.

Paulinus Nolanus, Epistulae, PL 61, 153-420.

Smaragus AbBas, Diadema monachorum, PL 102, 593-690.

Sulpicius Severus, Vita sancti Martini, ed. J. Fontaine, SCh 133, Paris 1967.

Synodus Sancti Patrici, PL 53, 817-822.

The Martylogy of Oengus the Culdee, ed. W. Stokes, Bublin 1984.

Walafridus Strabo, Vita Sancti Galii, PL 114, 975-1030.

\section{Opracowania}

AngenendT A., Die irische peregrination und ihre Auswirkungen auf dem Kontinent vor dem Jahre 800, w: Iren in Europa in frühen Mittelalter, hrsg. H. Löwe, cz. 1, Stuttgart 1982, 52-79.

Angenendt A., Monachi peregrini, München 1972.

BIELER L. von, Irland. Wegbereiter des mittelalters, Olten - Lausann - Freiburg im Breisgau 1969.

CAMPENHAUSEN H. von, Die asketische Heimatlosigkeit im altkirchlichen und frühmittelalterlichen Mönchtum, Tübingen 1930.

ChŁopowiec M., Pokuta w Kościele pierwszych wieków, Wrocław 2015.

DraczKowski F., Donatyzm, EK IV 111-113.

Gougaud L., Les conception du martyre chez les Irlandais, RBen 24 (1907) 360-373.

Grasmück E.L., Exilium. Untersuchungen zur Verbannung in der Antike, Paderborn 1978.

Heussi K., Der Ursprung des Mönchtums, Tübingen 1936.

Holl K., Enthusiasmus und Bussgewalt beim griechischen Mönchtum, Hildesheim 1969.

LECLERCQ J., De Saint Gregoire à saint Bernard du VI au XII siècles, w: La spiritualité du Moyen Âge, éd. J. Leclercq - F. Vandenbroucke - L. Bouyer, Paris 1961, 11-272.

Maurrou H.I., Od prześladowań Dioklecjana do śmierci Grzegorza Wielkiego (303-604), w: J. Danielou - H.I. Marrou, Historia Kościoła, t. 1: Od poczatków do roku 600, thum. M. Tarnowska, Warszawa 1986, 179-340.

Roux F. Le - Guyonvarc'H C.J., Keltische Religion, w: Handbuch der Religionsgeschichte, cz. 1, hrsg. J.P. Asmussen, Göttingen 1971, 245-276.

Vogel C., Le pèlerinage pénitentiel, RevSR 38 (1964) 113-153.

Wagemann J., Entwicklugsstufen des ältesten Mönchtums, Tübingen 1929.

Walh M. J.., Keltische und irische Askese, TRE IV 225-229.

WiPszycka E., Egipt - ojczyzna mnichów, w: Apoftegmaty Ojców Pustyni, t. 1: Gerontikon. Księga Starców, red. M. Starowieyski, ŹM 4, Kraków - Tyniec 2004², 15-64. 
